\title{
Effects of nickel on the fern Regnellidium diphyllum Lindm. (Marsileaceae)
}

\author{
Kieling-Rubio, MA. ${ }^{a}{ }^{*}$, Droste, $A .^{b}$ and Windisch, $P G^{a}{ }^{a}$ \\ aPrograma de Pós-graduação em Botânica, Universidade Federal do Rio Grande do Sul - UFRGS, \\ Av. Bento Gonçalves, 9500, CEP 91501-970, Porto Alegre, RS, Brazil

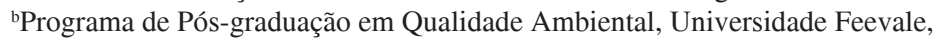 \\ Rod. RS-239 2755, CEP 93352-000, Novo Hamburgo, RS, Brazil \\ *e-mail: angelrubio@ig.com.br \\ Received August 9, 2011 - Accepted November 16, 2011 - Distributed November 30, 2012
}

(With 1 figure)

\begin{abstract}
The heterosporous fern Regnellidium diphyllum occurs in southern Brazil and some adjoining localities in Uruguay and Argentina. Currently it is on the list of threatened species in the state of Rio Grande do Sul. Anthropic alterations such as the conversion of wetlands into agricultural areas or water and soil contamination by pollutants may compromise the establishment and survival of this species. Nickel (Ni) is an essential nutrient for plants but increasing levels of this metal due to pollution can cause deleterious effects especially in aquatic macrophytes. Megaspore germination tests were performed using Meyer's solution, at concentrations of 0 (control), 0.05, 0.5, 1, 5, 10, 20, 30, 50 and $100 \mathrm{mg} \mathrm{L}^{-1}$ of $\mathrm{Ni}$. The initial development of apomictic sporophytes was studied using solutions containing 0 (control) to $4.8 \mathrm{mg} \mathrm{L}^{-1}$ of $\mathrm{Ni}$. A significant negative relation was observed between the different Ni concentrations and the megaspore germination/ sporophyte formation rates. Primary roots, primary leaves and secondary leaves were significantly shorter at 3.2 and $4.8 \mathrm{mg} \mathrm{L}^{-1}$ of Ni, when compared with the treatment without this metal. At $4.8 \mathrm{mg} \mathrm{L}^{-1}$, leaves also presented chlorosis and necrosis. The introduction of pollutants with $\mathrm{Ni}$ in the natural habitat of Regnellidium diphyllum may inhibit the establishment of plants in the initial stage of development, a problem to be considered in relation to the conservation of this species.
\end{abstract}

Keywords: heavy metals, megaspore, germination, sporophyte, pollution.

\section{Efeitos do níquel sobre a filicínea Regnellidium diphyllum Lindm. (Marsileaceae)}

\section{Resumo}

A samambaia heterosporada Regnellidium diphyllum Lindm. ocorre no Sul do Brasil e em algumas localidades vizinhas no Uruguai e na Argentina. Atualmente, consta da lista de espécies ameaçadas do Estado do Rio Grande do Sul. Alterações antrópicas - tais como a conversão de áreas úmidas em áreas de agricultura ou a contaminação de água e solo por poluentes - podem comprometer o estabelecimento e a sobrevivência da espécie. Níquel (Ni) é um nutriente essencial às plantas, mas níveis aumentados desse metal, em razão da poluição, podem causar efeitos deletérios, especialmente em macrófitas aquáticas. Testes de germinação de megásporos foram realizados usando-se solução de Meyer, em concentrações de 0 (controle); 0,05; 0,5; 1; 5; 10;20;30; 50; $100 \mathrm{mg} \mathrm{L}^{-1}$ de Ni. O desenvolvimento inicial de esporófitos apomíticos foi estudado usando-se soluções contendo 0 (controle) a $4,8 \mathrm{mg} \mathrm{L}^{-1}$ de Ni. Relação negativa significante foi observada entre diferentes concentrações de Ni e as taxas de germinação de megásporos/formação de esporófitos. Raízes primárias e folhas primárias e secundárias foram significantemente mais curtas a 3,2 e $4,8 \mathrm{mg} \mathrm{L}^{-1}$ de $\mathrm{Ni}$, quando comparadas ao tratamento sem esse metal. Em $4,8 \mathrm{mg} \mathrm{L}^{-1}$, folhas também apresentaram clorose e necrose. A introdução de poluentes com Ni no habitat natural de Regnellidium diphyllum pode inibir o estabelecimento de plantas em estádio inicial de desenvolvimento, um problemaa a ser considerado em relação à conservação dessa espécie.

Palavras-chave: metais pesados, megásporo, germinação, esporófito, poluição.

\section{Introduction}

Aquatic environments often receive high levels of pollutants from both direct and indirect sources. Chemical analyses of water and sediments alone do not provide information on the potential impact of polluting substances on organisms (Lovett-Doust et al., 1994). Heavy metals are added to water bodies as components of herbicides or as byproducts of different human activities. Some metals are essential for plants but when present beyond micronutrient 
levels, they may become toxic to aquatic organisms. Rooted macrophytes have been shown to be more sensitive to heavy metals than floating plants (Lewis, 1995).

Nickel (Ni) is a naturally occurring element that can be found in water, soil, sediments and in the air. It is an essential nutrient for plants, being involved in important metabolic processes, including ureolysis, hydrogen metabolism, methane biogenesis and acitogenesis (Mulrooney and Hausinger, 2003). However, the amount of $\mathrm{Ni}$ ( 0.01 to $5 \mu \mathrm{g} \mathrm{g}^{-1}$ dry weight) required for normal growth of plants is very low (Seregin and Kozhevnikova, 2006; Chen et al., 2009), and increasing levels of Ni from anthropogenic sources in different environments can cause deleterious effects in living organisms (Nickel Institute, 2011). Nriagu and Pacyna (1988) estimated that around 106 to 544 thousand tons of nickel are being added to the soil each year, resulting mainly from the metallurgical industry, fossil fuel combustion, and sewage sludge. In Brazil, there is no legislation establishing reference values of heavy metals in soil (Fadigas et al., 2002). In water, the current regulatory limit for $\mathrm{Ni}$ is $0.025 \mathrm{mg} \mathrm{L}^{-1}$ according to the Brazilian National Environmental Council - CONAMA (Brasil, 1986).

The heterosporous fern Regnellidium diphyllum Lindman occurs in southern Brazil and some adjoining localities in Uruguay and Argentina (Schultz, 1949; Alonso-Paz and Bassagoda, 2002) and figures on the endangered species list of the state of Rio Grande do Sul, Brazil (Rio Grande do Sul, 2011). The species grows in wetlands, the leaf lamina frequently floating and the rhizome developing in the humid soil or mud. Previous studies reported effects of heavy metals and other pollutants on the early development of $R$. diphyllum (Wunder et al., 2009; Cassanego et al., 2010; Droste et al., 2010; Kieling-Rubio et al., 2010).

The aim of this study was to investigate germination of megaspores and initial development of sporophytes of Regnellidium diphyllum in the presence of nickel, providing information on the influence of this metal in the establishment and growth of the species.

\section{Material and Methods}

Mature sporocarps of Regnellidium diphyllum were obtained from different plants in the municipality of Viamão (30 05' 00" S and 50 47' 00" W, Rio Grande do Sul state, Brazil) and kept at room temperature (about $25^{\circ} \mathrm{C}$ ). Voucher specimens were deposited in the Herbarium Anchieta (PACA), Universidade do Vale do Rio dos Sinos, São Leopoldo, Brazil.

After washing in tap water, sporocarps were rinsed in $70 \%$ ethanol solution, kept for 10 minutes in $7 \%$ sodium hypochlorite solution, then washed in sterile distilled water and dried on sterile filter paper at room temperature in a flow chamber. Sporocarps were mechanically cracked to liberate the spores. Megaspores were manually isolated from microspores under a stereomicroscope. Megaspores from sporocarps of different plants were mixed to obtain a representative sample of the population. Taking into account the common occurrence of apogamy in megagametophytes of Regnellidium diphyllum (Mahlberg and Baldwin, 1975), only megaspores were used in order to obtain uniform cultures, thus avoiding the mixture of sexually and apomictically formed sporophytes. As culture medium, Meyer's solution (Meyer et al., 1955) was prepared and $\mathrm{pH}$ was adjusted with $\mathrm{NaOH}$ to 6.0 before autoclaving. Nickel was added to the medium after autoclaving, from a standard solution of Titrisol ${ }^{\circledR} 1000 \mathrm{mg} \mathrm{L}^{-1}$. Two experiments were conducted and the culture vials were maintained in a growth chamber at $24 \pm 1{ }^{\circ} \mathrm{C}$, under artificial light with nominal irradiance of $77 \mu \mathrm{mol} \mathrm{m} \mathrm{m}^{-2} \mathrm{~s}^{-1}$ and a 12-hour photoperiod.

In the experiment $\mathrm{I}$, germination was evaluated at 0 (control), 0.05, 0.5, 1, 5, 10, 20, 30, 50 and $100 \mathrm{mg} \mathrm{L}^{-1} \mathrm{Ni}$. Twenty-five megaspores were placed in each glass vial $(4.5 \times 10 \mathrm{~cm})$ with $25 \mathrm{~mL}$ of the culture medium, with four repetitions for each treatment. Megaspores showing at least one globular green structure with a crown of rhizoids were considered as germinated. At the end of 21 days, germinated megaspores were counted and classified in two types; those without any further development and those showing sporophytes, according to Kieling-Rubio et al. (2010). The percentages of germinated megaspores and the percentages of sporophytes formed were calculated. In the experiment II, sporophytic development was evaluated at 0 (control), 0.025, 0.05, 0.1, 0.2, 0.4, 0.8, 1.6, 3.2 and $4.8 \mathrm{mg} \mathrm{L}^{-1} \mathrm{Ni}$. Fifteen megaspores were placed in each glass vial with $20 \mathrm{~mL}$ of the culture medium, with five repetitions for each treatment. Ten individuals were eliminated randomly from each glass vial at the end of seven days, thus maintaining five individuals in each repetition. The length of the primary root and the length of the primary and secondary leaves were measured for each individual after 7 and 28 days in a laminar flow chamber.

Data were tested for normality using the KolmogorovSmirnov tests. Linear regression analysis was applied to estimate (a) the relation between the Ni concentrations and the percentages of germinated megaspores and (b) the relation between the Ni concentrations and the percentages of sporophytes formed. The mean values of the length of roots, primary and secondary leaves were compared using the Kruskal-Wallis test, followed by the Dunn test, with $\alpha=0.05$. The analyses were conducted using SPSS 17.0 and BioEstat 5.0 softwares.

\section{Results}

There was a significant negative relation between the $\mathrm{Ni}$ concentrations and the percentage of germination evaluated at the end of 21 days of culture, as an observable linear regression (Figure 1). While in the absence of Ni, $80 \%$ of the megaspores germinated, concentrations of $0.05 \mathrm{mg} \mathrm{L}^{-1}$ and higher of these metal caused a gradual decrease of the germination percentages, declining from 75 to $45 \%$. The percentages of sporophytes formed also presented a significant negative relation with the Ni concentrations tested. While $78 \%$ of the megaspores cultivated in the absence of $\mathrm{Ni}$ formed sporophytes, in the presence of this 
metal a gradual decrease of these percentages could be observed, from $67 \%$ at $0.05 \mathrm{mg} \mathrm{L}^{-1}$ to $14 \%$ at $30 \mathrm{mg} \mathrm{L}^{-1}$. No sporophytes were formed at both highest $\mathrm{Ni}$ concentrations tested (Figure 1).

Experiment II evidenced that after seven days of culture, the length of the primary roots and primary leaves were significantly lower at $4.8 \mathrm{mg} \mathrm{L}^{-1}$ of $\mathrm{Ni}$ than in the control. After 28 days, primary roots, primary leaves and secondary leaves were significantly shorter in treatments with 3.2 and $4.8 \mathrm{mg} \mathrm{L}^{-1}$ of $\mathrm{Ni}$, comparing with the control. At $4.8 \mathrm{mg} \mathrm{L}^{-1}$ of $\mathrm{Ni}$, secondary leaves were formed only at 28 days in culture (Table 1 ).

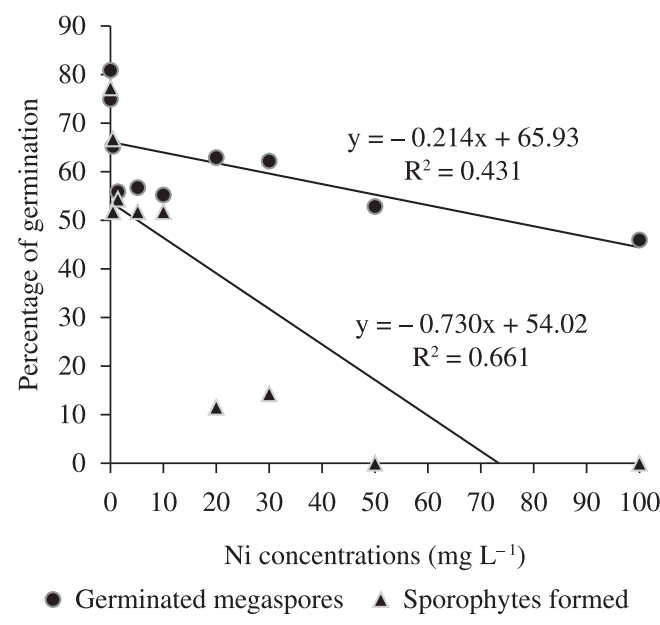

Figure 1. Relation of the germination percentages of Regnellidium diphyllum Lindman megaspores and $\mathrm{Ni}$ concentrations at the end of 21 days of culture. (Germinated megaspores: $\mathrm{F}=6.059 ; \mathrm{p}=0.039$. Sporophytes formed: $F=15.600 ; p=0.004)$. ( $R^{2}=$ squared multiple $R$ value; $\mathrm{F}=$ statistics of the ANOVA test; $\mathrm{p}=$ probability).
After 28 days, small and morphologically anomalous leaves could be observed in a reduced number of individuals at 3.2 and $4.8 \mathrm{mg} \mathrm{L}^{-1}$ of Ni. Plantlets exposed to these $\mathrm{Ni}$ concentrations showed visible symptoms of leaf chlorosis and necrosis, as well as necrotic areas in the roots, especially at the highest $\mathrm{Ni}$ concentration tested.

\section{Discussion}

Toxic effects of $\mathrm{Ni}$ on germination and plant growth might be due to its interference with other essential metal ions and induction of oxidative stress (Chen et al., 2009), poor elasticity of cell walls and disturbed mitotic activities (Seregin and Kozhevnikova, 2006), as well as suppression of the activity of hydrolytic enzymes (Walker et al., 1985).

The different nickel concentrations tested in the present study influenced negatively megaspore germination, formation of sporophytes and sporophytic development of Regnellidium diphyllum. The growth reduction of roots and leaves of this species was recorded in previous in vitro experiments with other metals. Just as nickel, cadmium added to the culture medium at concentration of $50 \mathrm{mg} \mathrm{L}^{-1}$ resulted in a significant reduction of germination, and no germination was observed at $100 \mathrm{mg} \mathrm{L}^{-1}$ (Wunder et al., 2009). Growth of primary roots and primary leaves were significantly reduced in cadmium concentrations between 12.5 and $50 \mathrm{mg} \mathrm{L}^{-1}$, and no secondary leaves were formed (Wunder et al., 2009). Decreased megaspore germination with subsequent sporophytic development was verified from $0.5 \mathrm{mg} \mathrm{L}^{-1}$ chromium (VI) concentration onwards, while growth of primary roots and primary and secondary leaves was significantly reduced in $3.2 \mathrm{mg} \mathrm{L}^{-1}$ concentration or higher (Kieling-Rubio et al., 2010).

For Azolla filiculoides Lam., a decrease of $31 \%$ in the biomass was observed when this aquatic fern was cultivated at $4 \mathrm{mg} \mathrm{L}^{-1}$ of Ni during a period of 15 days (Khosravi et al.,

Table 1. Influence of different nickel concentrations on the growth of Regnellidium diphyllum Lindman. Mean length of primary root, primary and secondary leaves after 7 and 28 days in culture (mean \pm standard deviation). $(\mathrm{H}=$ statistics of the Kruskal-Wallis test; $\mathrm{p}=$ probability).

\begin{tabular}{|c|c|c|c|c|c|c|}
\hline \multirow{2}{*}{$\frac{\text { Nickel }}{\left(\mathrm{mg} \mathrm{L}^{-1}\right)}$} & \multicolumn{2}{|c|}{ Primary root $(\mathrm{mm})$} & \multicolumn{2}{|c|}{ Primary leaf (mm) } & \multicolumn{2}{|c|}{ Secondary leaf (mm) } \\
\hline & 7 days & 28 days & 7 days & 28 days & 7 days & 28 days \\
\hline 0.0 & $5.72 \pm 1.30$ & $6.80 \pm 0.72$ & $8.0 \pm 0.86$ & $10.12 \pm 0.50$ & $0.86 \pm 0.43$ & $9.04 \pm 0.75$ \\
\hline 0.025 & $4.14 \pm 2.57$ & $4.88 \pm 3.03$ & $6.62 \pm 3.80$ & $8.28 \pm 4.24$ & $0.86 \pm 0.64$ & $8.45 \pm 4.60$ \\
\hline 0.05 & $3.01 \pm 0.67 *$ & $4.36 \pm 1.26^{*}$ & $5.28 \pm 1.47$ & $7.32 \pm 2.11 *$ & $0.46 \pm 0.31$ & $7.72 \pm 1.80$ \\
\hline 0.1 & $4.22 \pm 0.92$ & $5.42 \pm 1.68$ & $11.1 \pm 28.75$ & $9.36 \pm 1.44$ & $0.54 \pm 0.36$ & $9.56 \pm 1.51$ \\
\hline 0.2 & $3.62 \pm 0.72$ & $4.80 \pm 0.88^{*}$ & $6.06 \pm 0.62$ & $8.64 \pm 1.08 *$ & $0.44 \pm 0.32$ & $8.86 \pm 1.03$ \\
\hline 0.4 & $2.42 \pm 0.68 *$ & $3.30 \pm 1.40 *$ & $5.40 \pm 1.18$ & $7.96 \pm 1.60$ & $0.50 \pm 0.32$ & $8.44 \pm 1.63$ \\
\hline 0.8 & $5.46 \pm 0.81$ & $6.66 \pm 0.70$ & $8.68 \pm 0.59$ & $10.56 \pm 1.29$ & $0.86 \pm 0.33$ & $9.66 \pm 2.02$ \\
\hline 1.6 & $6.14 \pm 2.05$ & $7.04 \pm 2.25$ & $9.06 \pm 1.93$ & $10.92 \pm 2.69$ & $0.90 \pm 0.53$ & $8.60 \pm 1.32$ \\
\hline 3.2 & $3.24 \pm 1.80$ & $4.26 \pm 1.87 *$ & $4.46 \pm 1.81 *$ & $6.26 \pm 1.98 *$ & $0.26 \pm 0.37$ & $6.04 \pm 2.44 *$ \\
\hline 4.8 & $0.64 \pm 1.43 *$ & $1.16 \pm 2.59^{*}$ & $1.02 \pm 2.28 *$ & $1.52 \pm 3.40 *$ & $0.00 *$ & $1.68 \pm 3.76^{*}$ \\
\hline & $\begin{array}{c}H=82.450 \\
p<0.001\end{array}$ & $\begin{array}{c}\mathrm{H}=124.331 \\
\mathrm{p}<0.001\end{array}$ & $\begin{array}{c}H=103.993 \\
p<0.001\end{array}$ & $\begin{array}{c}H=126.993 \\
p<0.001\end{array}$ & $\begin{array}{c}H=34.666 \\
p=0.014\end{array}$ & $\begin{array}{c}H=96.961 \\
p=0.033\end{array}$ \\
\hline
\end{tabular}

*Indicates significantly lower means than those observed in the treatment without nickel in the same column (Dunn test $-\mathrm{p}<0.05)$. 
2005). Piccini and Malavolta (1992) evaluated Ni toxicity in different bean cultivars using nutrient solution and verified that bean production was inversely related to $\mathrm{Ni}$ concentrations, and that in the presence of $4 \mathrm{mg} \mathrm{L}^{-1}$ of $\mathrm{Ni}$, plants did not produced seeds. Peralta et al. (2001) tested the effects of $\mathrm{Ni}$ on the roots and plant growth of alfalfa (Medicago sativa L.). They measured root length and found approximately $51 \%$ inhibition of root elongation at a $\mathrm{Ni}$ concentration of $0.68 \mathrm{mM}$. A similar result was obtained by Soudek et al. (2010), who verified 30 to $70 \%$ inhibition of flax (Linum usitatissimum L.) root elongation at a concentration of $0.5 \mathrm{mM}$ of $\mathrm{Ni}$.

Chlorosis and necrosis showed by sporophytes of Regnellidium diphyllum in the presence of $\mathrm{Ni}$ was also observed in newly developed leaves of Ipomoea aquatic Forsk treated with 0.085 to $0.255 \mathrm{mM}$ of $\mathrm{Ni}$ for a week (Sun and $\mathrm{Wu}, 1998$ ). Plants of Phaseolus vulgaris $\mathrm{L}$. treated with $100 \mathrm{mg} \mathrm{L}^{-1}$ of $\mathrm{Ni}$ showed chlorotic leaves with gray spots that coalesced and became necrotic (Campanharo et al., 2010). Symptoms like chlorosis and necrosis can occur due to the excess of $\mathrm{Ni}$ (Seregin and Kozhevnikova, 2006), but other essential metals also can cause them (Khalid and Tinsley, 1980). This may be due to the fact that $\mathrm{Ni}$ has some characteristics that are similar to calcium, magnesium, manganese, iron, copper and zinc (Yusuf et al., 2011). Therefore, Ni may compete with essential metals in absorption, uptake and their subsequent utilization in the plant system (Barcelo and Poschenrieder, 1990; Chen et al., 2009).

Considering the results obtained in the present study, pollutant human activities that introduce $\mathrm{Ni}$, even in low doses, in the natural habitat of Regnellidium diphyllum, may inhibit the establishment of plants in the initial stage of development and threatening their populations, a problem to be considered in relation to the conservation status of this currently vulnerable species.

Acknowledgements - The authors are grateful to the Universidade do Vale do Rio dos Sinos - UNISINOS, São Leopoldo, RS, for the use of laboratories and for the scholarship granted to the first author, through the Graduate Programme in Biology, to the Universidade Feevale, to the Universidade Federal do Rio Grande do Sul (UFRGS) and to the Conselho Nacional de Desenvolvimento Científico e Tecnológico (CNPq) for the support and research grants. Dr. Jairo L. Schmitt provided welcome suggestions.

\section{References}

ALONSO-PAZ, E. and BASSAGODA, MJ., 2002. Revisión de las Marsileaceae del Uruguay y primera cita de Pilularia americana A. Braun. Comunicaciones Botanicas-Museos Nacionales de Historia Natural y Antropologia, vol. 125, no. 6, p. 18.

BARCELO, J. and POSCHENRIEDER, CH., 1990. Plant water relations as affected by heavy metal stress: a review. Journal of Plant Nutrition, vol. 13, p.1-37. http://dx.doi. org/10.1080/01904169009364057

Brasil. Ministério do Meio Ambiente - MMA, 1986. Resolução CONAMA nº 20 , de 18 de junho de 1986. Dispõe sobre a classificação das águas e estabelece os limites máximos das substâncias potencialmente prejudiciais. Diário Oficial da República Federativa do Brasil, Poder Executivo, Brasília, DF, 30 jul. 1986. Seção 2, p. 8.

CAMPANHARO, M., MONNERAT, PH., ESPINDULA, MC., RABELLO, WS. and RIBEIRO, G., 2010. Toxicity symptoms of nickel in common bean. Revista Ciência Agronômica, vol. 4, no. 3 , p. $490-494$.

CASSANEGO, MBB., DROSTE, A. and WINDISCH, PG., 2010. Effects of 2,4-D on the germination of megaspores and initial development of Regnellidium diphyllum Lindman (Monilophyta, Marsileaceae). Brazilian Journal of Biology, vol. 70, no. 2, p. 361-366. http://dx.doi.org/10.1590/S1519-69842010005000014

CHEN, C., HUANG, D. and LIU, J., 2009. Functions and Toxicity of Nickel in Plants: Recent Advances and Future Prospects. Clean, vol. 37, no. 4-5, p. 304-313.

DROSTE, A., CASSANEGO, MBB. and WINDISCH, PG. 2010. Germination and sporophytic development of Regnellidium diphyllum Lindm. (Marsileaceae) in the presence of a glyphosatebased herbicide. Revista Brasileira de Biociências, vol. 8, no. 2, p. 174-178.

FADIGAS, FS., AMARAL-SOBRINHO, NMB., MAZUR, N., ANJOS, LHC. and FREIXO, AA., 2002. Concentrações naturais de metais pesados em algumas classes de solos brasileiros. Bragantia, vol. 61, no. 2, p. 151-159. http://dx.doi.org/10.1590/ S0006-87052002000200008

KHALID, BY. and TINSLEY, J., 1980. Some effects of nickel toxicity on ryegrass. Plant Soil, vol. 55, p. 139-144. http://dx.doi. org/10.1007/BF02149717

KHOSRAVI, M., GANJI, MT. and RAKHSHAEE, R., 2005. Toxic effect of $\mathrm{Pb}, \mathrm{Cd}, \mathrm{Ni}$ and $\mathrm{Zn}$ on Azolla filiculoides in the International Anzal Wetland. International Journal of Environmental Science and Technology, vol. 2, no. 2, p. 35-40.

KIELING-RUBIO, MA., DROSTE, A. and WINDISCH, PG., 2010. Germination and sporophytic development of Regnellidium diphyllum Lindman (Marsileaceae) in the presence of hexavalent chromium. Brazilian Journal of Biology, vol. 70, no. 4 Suppl., p. 1149-1153. http://dx.doi.org/10.1590/S1519-69842010000600003

LEWIS, MA., 1995. Use of freshwater plants for phytotoxicity testing: a review. Environmental Pollution, vol. 87, p. 319-336. http://dx.doi.org/10.1016/0269-7491(94)P4164-J

LOVETT-DOUST, L., LOVETT-DOUST, J. and BIERNACKI, M., 1994. American wildcelery, Vallisneria americana, as a biomonitor of organic contaminants in aquatic ecosystems. Journal of Great Lakes Research, vol. 20, p. 333-354. http:// dx.doi.org/10.1016/S0380-1330(94)71152-7

MAHLBERG, PG. and BALDWIN, M., 1975. Experimental studies on megaspore viability, parthenogenesis and sporophyte formation in Marsilea, Pilularia and Regnellidium. Botanical Gazette, vol. 136, no. 3, p. 269-273. http://dx.doi.org/10.1086/336813

MEYER, BS., ANDERSON, DB. and SWANSON, CA., 1955. Laboratory Plant Physiology. Princeton: Van Nostrand, 168 p.

MULROONEY, SB. and HAUSINGER, RP., 2003. Nickel uptake and utilization by microorganisms. FEMS Microbiology Reviews, vol. 27, p. 239-261. http://dx.doi.org/10.1016/S01686445(03)00042-1

Nickel Institute. Health \& Environment: Emissions to environment. Available from: <http://www.nickelinstitute.org/index.cfm?ci_ id=16081\&la_id=1>. Access in: 01 jun. 2011. 
NRIAGU, JO. and PACYNA, JM., 1988. Quantitative assessment of worldwide contamination of air, waters and soils with trace metal. Nature, vol. 333, p. 134-139. PMid:3285219. http://dx.doi. org/10.1038/333134a0

PERALTA, JR., GARDEA-TORRESDEY, JL., TIEMANN, KJ., GOMEZ, E., ARTEAGA, S., RASCON, E. and PARSONS, JG., 2001. Uptake and effects of five heavy metals on seed germination and plant growth in alfalfa (Medicago sativa L.). Bulletin of Environmental Contamination and Toxicology, vol. 66, p. 727-734. PMid:11353374.

PICCINI, DF. and MALAVOLTA, E., 1992. Effect of nickel on two common bean cultivars. Journal of Plant Nutrition, vol. 15, p. 2343-2350. http://dx.doi.org/10.1080/01904169209364478

Rio Grande do Sul. Secretaria do Meio Ambiente - SEMA. Espécies da flora ameaçadas de extinção do Rio Grande do Sul. Porto Alegre: Secretaria do Meio Ambiente. Available at: <http:// www.sema.rs.gov.br/sema/html/pdf/especies-ameacadas.pdf $>$. Access: 05 jul. 2011.

SCHULTZ, AR., 1949. Contribuições ao conhecimento de Regnellidium diphyllum Lindmann. Lilloa, vol. 17, p. 139-144.

SEREGIN, IV. and KOZHEVNIKOVA, AD., 2006. Physiological role of nickel and its toxic effects on higher plants. Russian Journal of Plant Physiology, vol. 53, p. 257-277. http://dx.doi. org/10.1134/S1021443706020178
SOUDEK, P., KATRUSÁKOVÁ, A., SEDLÁCEK, L., PETROVÁ, S., KOCÍ, V., MARSIK, P., GRIGA, M. and VANEK, T., 2010. Effect of heavy metals on inhibition of root elongation in 23 cultivars of flax (Linum usitatissimum L.). Archives of Environmental Contamination and Toxicology, vol. 59, p. 194-203. PMid:20174789. http://dx.doi.org/10.1007/s00244-010-9480-y

SUN, EJ. and WU, FY., 1998. Along-vein necrosis as indicator symptom on water spinach caused by nickel in water culture. Botanical Bulletin of Academia Sinica, vol. 39, p. 255-259.

WALKER, CD., GRAHAM, RD., MADISON, JT., CARY, EE. and WELCH, RM., 1985. Effects of Ni deficiency on some nitrogen metabolites in cowpeas (Vigna unguiculata L. Walp). Plant Physiology, vol. 79, p. 474-479. PMid:16664434 PMCid:1074909. http://dx.doi.org/10.1104/pp.79.2.474

WUNDER, DA., DROSTE, A. and WINDISCH, PG., 2009. Megaspore germination and initial development of Regnellidium diphyllum Lindman (Pteridophyta, Marsileaceae) sporophytes in the presence of cadmium. Revista Brasileira de Botânica, vol. 31, p. 177-181.

YUSUF, M., FARIDUDDIN, Q., HAYAT, S. and AHMAD, A., 2011. Nickel: An Overview of Uptake, Essentiality and Toxicity in Plants. Bulletin of Environmental Contamination and Toxicology, vol. 86, p. 1-17. PMid:21170705. http://dx.doi. org/10.1007/s00128-010-0171-1 
